DOI https://doi.org/10.30525/978-9934-26-173-2-40

\title{
ДОСВІД ВИКЛАДАННЯ НАВЧАЛЬНОЇ ДИСЦИПЛІНИ «МОЛЕКУЛЯРНА БІОЛОГІЯ» В ОДЕСЬКОМУ НАЦІОНАЛЬНОМУ МЕДИЧНОМУ УНІВЕРСИТЕТІ
}

\author{
Левицька Н. А. \\ кандидатка медичних наук, \\ доцентка кафедри клінічної імунології, генетики і медичної біологї \\ Одеський національний медичний університет \\ Пашолок С. П. \\ кандидат медичних наук, \\ дочент кафедри клінічної імунології, генетики і медичної біології \\ Одеський національний медичний університет \\ Бажора Ю. I. \\ доктор медичних наук, \\ професор кафедри клінічної імунології, генетики і медичної біології \\ Одеський національний медичний університет \\ м. Одеса, Україна
}

Молекулярна біологія є однією 3 навчальних дисциплін природознавства, яка зазнає бурхливого розвитку. Молекулярні основи структури та функцій клітин різних тканин, їх взаємодії, процесів росту, розмноження та загибелі, які відбуваються в них, патологічних процесів їхньої життєдіяльності визначають клінічні прояви хвороби та мають досить-таки велике значення для діагностики, лікування та профілактики. Ці знання необхідні не тільки студентам-біологам, а й майбутнім лікарям різних спеціальностей.

На кафедрі клінічної імунології, генетики і медичної біології Одеського національного медичного університету створено єдину навчальну концепцію з викладання медичної біології - базису сучасної медицини. 3 цією метою співпрацівники кафедри ініціювали написання ряду підручників і навчальних посібників для студентів від 1-го до 5-го курсів включно [1].

Особливою популярністю серед здобувачів вищої медичної освіти користується підручник «Медична біологія», який витримав три видання та готується четверте. Він $є$ базовим для студентів усіх медвишів України. Крім того, два видання витримав підручник для англомовних студентів міжнародного факультету. 
На кафедрі вже протягом багатьох років відбуваються короткі курси навчання 3 медичної генетики лікарів-інтернів (сімейні лікарі лікарі загальної практики, акушери-гінекологи, судові лікарі тощо). При цьому особлива увага приділяється останнім досягненням молекулярної медицини. Великою популярністю користуються лекції 3 фармакогенетики [2].

Важливе місце у викладанні молекулярної біології на кафедрі приділяється впровадженню в навчальний процес результатів, які отримано співпрацівниками при виконанні наукових досліджень, у тому числі - з молекулярної біології [3].

Студенти Одеського національного медичного університету мають змогу ознайомлюватись із головними макромолекулярними біополімерами - білками та нуклеїновими кислотами, а також надмолекулярними структурами клітини за наскрізною програмою на різних кафедрах від першого до останнього курсів. Вони вивчають молекулярні механізми основних біологічних процесів у клітині - відтворення та реалізацію спадкової інформації в процесі біологічного синтезу білків, структурнофункціональну організацію та взаємодії білків і нуклеїнових кислот, регуляторні механізми цих процесів у евкаріот. Крім того, студенти вивчають організацію макромолекул і надмолекулярних структур, молекулярні механізми процесів синтезу ДНК, РНК та протеїнів у прокаріот і евкаріот, а також транспорт речовин через біологічну мембрану (плазмалему).

Особливу увагу приділяємо ознайомленню студентів із основними кількісними і якісними методами молекулярної біології, як от: полімеразная ланцюгова реакція, електронна мікроскопія, рентгеноструктурний аналіз, хроматографія, гель-електрофорез, флуорометрія, спектроскопія, імуноферментний аналіз, метод клітинних культур, метод генетичних маркерів, метод перенесення генів за допомогою вірусних векторів або плазмід тощо.

Також приділяємо велику увагу молекулярним підходам клітинної біології в практичній охороні здоров'я, тобто молекулярній медицині, створенню нових лікарських препаратів i діагностики багатьох захворювань. Наведемо лише один приклад. Ізраїльськими науковцями було створено ліки для боротьби 3 хворобою Альцгеймера - «молекулярні ножиці», які видаляють альфа-амілоїдні бляшки, що є чинником розвитку цієї хвороби.

Студенти - учасники наукового гуртка кафедри виступають iз доповідями на студентських олімпіадах i науково-практичних конференціях, на яких неодноразово займали призові місця. 
Наприклад, на перших курсах студенти готують реферати, в яких розглядають цікаві особливості молекулярної біології на науковопопулярному рівні. Для прикладу. Як із неживих хімічних молекул водню, вуглецю, кисню та сірки складається злагоджена система в живому організмі? Як із одноклітинної заплідненої яйцеклітини (зиготи) формуються 220 різних типів клітин? Як працює ДНК, яка є сховищем спадкової інформації?

Таким чином, знайомлячи студентів і лікарів-інтернів із основами молекулярної біології на стику 3 класичною біологією, надіємося, що ці знання стануть фундаментальною основою для їх теоретичної підготовки, яка знадобиться подальшій практичній діяльності.

\title{
Література:
}

1. Бажора Ю. І., Чернецька О. В. Сучасні технології навчання. Одеський медичний журнал. 2010. № 4 (120). С. 33-37.

2. Бажора Ю. І. Фармакогенетика: досягнення та перспективи. 2003. $140 \mathrm{c}$.

3. Бажора Ю. І., Гончарук С. Ф. До проблеми інтеграції викладання медико-біологічних i клінічних дисциплін у медичних вишах. Ліки - людині. 2003. С. 401-403.

DOI https://doi.org/10.30525/978-9934-26-173-2-41

\section{ВИКОРИСТАННЯ МІЖДИСЦИПЛІНАРНОГО ПІДХОДУ У ПРОЦЕСІ ОБГРУНТУВАННЯ ЕКОНОМІЧНОЇ СКЛАДОВОЇ ПІДГОТОВКИ МАЙБУТНІХ ПЕДАГОГІВ ПРОФЕСІЙНОГО НАВЧАННЯ}

\author{
Ляшенко М. Ю. \\ кандидат педагогічних наук, дочент, \\ доцент кафедри теорії та методики професійної підготовки \\ Національний педагогічний університет імені М. П. Драгоманова \\ м. Київ, Україна
}

Щороку у закладах вищої освіти відбувається оновлення та удосконалення змістовного наповнення навчальних дисциплін як одного 3 важливих компонентів освітньої програми. Проте в останні роки спостерігається тенденція до зменшення економічної складової в навчальних планах педагогів професійного навчання. Актуальність 154 